\title{
ANALISIS IMPLEMENTASI BASIS AKRUAL PADA LAPORAN KEUANGAN BADAN PENGELOLAAN KEUANGAN DAN ASET DAERAH KOTA PALEMBANG
}

\author{
Kemas Welly Angga Permana \\ Universitas Sjakhyakirti Palembang \\ Email: kemaswelly@unisti.ac.id
}

\begin{abstract}
ABSTRAK
Tujuan penelitian ini adalah untuk mengetahui implementasi basis akrual pada laporan keuangan Badan Pengelolaan Keuangan dan Aset Daerah Kota Palembang. Data yang digunakan dalam penelitian ini adalah data sekunder yang diperoleh dari Badan Pengelolaan Keuangan dan Aset Daerah Kota Palembang. Metode penelitian ini merupakan penelitian deskriptif kualitatif yang berfokus pada penjelasan sistematis tentang fakta yang diperoleh pada saat penelitian ini dilakukan.

Hasil penelitian menunjukkan bahwa Implementasi basis akrual pada laporan keuangan Badan Pengelolaan Keuangan dan Aset Daerah Kota Palembang masih belum sesuai dengan Peraturan Pemerintah Republik Indonesia Nomor 71 Tahun 2010 dalam menyajikan laporan keuangannya. Ketidaksesuaian ini terjadi pada 3 laporan yang disajikan Badan Kepegawaian dan Pengembangan Sumber Daya Manusia Kota Palembang yang tidak sesuai dengan tata cara penyajian yang tercantum pada Peraturan Pemerintah Republik Indonesia Nomor 71 Tahun 2010 tentang Standar Akuntansi pemerintah.

Aplikasi penelitian ini disarankan bagi Badan Pengelolaan Keuangan dan Aset Daerah Kota Palembang agar lebih memperhatikan kesesuaian dalam penyajian laporannya terutama untuk laporan realisasi anggaran dan laporan perubahan ekuitas serta Catatan atas Laporan Keuangan dan bagi Pemerintah Kota Palembang kiranya perlu ada upaya akselerasi sinkronisasi standar akuntansi pemerintahan berbasis akrual berdasarkan Peraturan Pemerintah Republik Indonesia Nomor 71 Tahun 2010 dengan peraturan lokal di pemerintah daerah.

Kata Kunci: Basis Akrual, Laporan Keuangan, Standar Akuntansi Pemerintah.
\end{abstract}

\section{PENDAHULUAN}

\subsection{LATAR BELAKANG}

Badan Pengelolaan Keuangan dan Aset Daerah Kota Palembang merupakan lembaga unsur SKPD Pemerintah Daerah Kota Palembang yang dipimpin oleh seorang Kepala Badan, yang berada dibawah dan bertanggungjawab kepada Walikota melalui Sekretaris Daerah Kota Palembang. Dalam melaksanakan tugas pokok dan fungsi serta sebagai upaya pencapaian visi 
dan misi Pemerintah Kota Palembang, Badan Pengelolaan Keuangan dan Aset Daerah Kota Palembang selalu berupaya untuk terus meningkatkan kinerjanya, sesuai dengan cita-cita yang ingin diwujudkan secara objektif, realistis, dan dengan pencapaian yang dapat diindikasikan berdasarkan ukuran-ukuran tertentu.

Dampak positif dari penerapan akuntansi pemerintahan berbasis akrual telah banyak diakui oleh para peneliti. Seperti kajian yang dilakukan oleh berguna bagi Pemerintah Daerah Kota Palembang sebagai masukan dan sumber informasi mengenai penerapan akuntansi akrual, permasalahan yang dihadapi dan solusi yang diambil dalam mengatasi masalah tersebut. Hasil penelitian ini juga diharapkan dapat memberi masukan dalam mendukung pelaksanaan PP 71 tahun 2010 dan Permendagri No.64 Tahun 2013 tentang penerapan SAP berbasis akrual pada Pemerintah Daerah Pembahasan selanjutnya penelitian ini dimulai dengan kajian pustaka yang berhubungan dengan akuntansi berbasis akrual.

Pada tahun 2015, seluruh instansi pemerintah baik yang ada di pusat maupun di daerah harus sudah menerapkan Standar Akuntansi Pemerintah (SAP) berbasis akrual (accrual basis). Setelah aturan SAP berbasis akrual ditandatangani maka pemerintah pusat dan daerah harus sudah menerapkan SAP per 1 Januari 2015, dasar hukum penerapan SAP berbasis akrual adalah PP No.71/2010 tentang SAP, sebagai amanat dari UU No. 17/2003 tentang Keuangan Negara. UU No. 17/2003 mengamanatkan instansi pemerintah baik di pusat maupun di daerah di minta untuk menerapkan SAP berbasis akrual. PP No. 71/2010 disebutkan SAP berbasis akrual dilaksanakan empat tahun setelah tahun 2010, yang artinya dilaksanakan pada tahun 2015.

Sistem akuntansi keuangan daerah merupakan salah satu subsistem organisasi yang memfasilitasi kontrol dengan melaporkan kinerja pemerintah daerah. Ruang lingkup sistem akuntansi keuangan daerah mencakup kebijakan sistem akuntansi, prosedur sistem akuntansi, sumber daya manusia, dan teknologi informasi. Basis akrual atau accrual basis pada dasarnya adalah suatu metode akuntansi dimana penerimaan dan pengeluaran diakui atau dicatat ketika transaksi terjadi. Dengan demikian pencatatan dalam metode ini bebas dari pengaruh waktu kapan kas diterima dan kapan pengeluaran dilakukan. Hal yang penting adalah ketika transaksi terjadi langsung dicatat, karena transaksi tersebut memiliki 
implikasi uang masuk atau keluar di masa depan. Transaksi di catat pada saat terjadi, walaupun uang belum benar-benar diterima atau dikeluarkan. Basis akrual digunakan untuk pengukuran aset, kewajiban dan ekuitas dana (Beechy, 2007).

Manfaat basis akrual secara nyata dirasakan dalam menyajikan informasi atas seluruh aktivitas yang terjadi. Widjajarso dalam Sari dan Putra (2012:4) memaparkan alasan penerapan basis akrual pada sektor pemerintahan, diantaranya yaitu akuntansi berbasis kas tidak menghasilkan informasi yang cukup, misalnya informasi tentang hutang dan piutang untuk pengambilan keputusan ekonomi, sehingga penggunaan basis akrual sangat disarankan, hanya akuntansi berbasis akrual menyediakan informasi yang tepat untuk menggambarkan biaya operasi yang sebenarnya, hanya akuntansi berbasis akrual yang dapat menghasilkan informasi yang dapat diandalkan dalam informasi aset dan kewajiban, dan hanya akuntansi berbasis akrual yang menghasilkan informasi keuangan yang komprehensif tentang pemerintah, misalnya penghapusan hutang yang tidak ada pengaruhnya di laporan berbasis kas. PP No.71 Tahun 2010 pasal 1 ayat 8 menyatakan bahwa standar akuntansi pemerintahan berbasis akrual adalah "standar akuntansi pemerintahan yang mengakui pendapatan, beban, aset, utang, dan ekuitas dalam pelaporan finansial berbasis akrual, serta mengakui pendapatan, belanja, dan pembiayaan dalam pelaporan pelaksanaan anggaran berdasarkan basis yang ditetapkan dalam APBN/APBD”. Basis Akrual untuk neraca berarti bahwa aset, kewajiban dan ekuitas dana diakui dan di catat pada saat terjadinya transaksi, atau pada saat kejadian atau kondisi lingkungan berpengaruh pada keuangan pemerintah, tanpa memperhatikan saat kas atau setara kas di terima atau di bayar. Sampai dengan tahun anggaran 2013, pemerintah daerah masih menerapkan SAP berdasarkan Peraturan Pemerintah Nomor 24 Tahun 2005 tentang Standar Akuntansi Pemerintahan. Perbedaan fundamental Peraturan Pemerintah Nomor 71 Tahun 2010 dengan Peraturan Pemerintah Nomor 24 Tahun 2005 terletak pada basis pencatatan transaksi dan jenis laporan keuangan.

Tantangan penerapan akuntansi berbasis akrual pada Pemerintah Daerah Kota Palembang dapat dijelaskan, sistem akuntansi dan Information Technology (IT) Based System, yaitu belum tersedianya sistem akuntansi dan sistem teknologi informasi yang mampu mengakomodasi persyaratan-persyaratan dalam penerapan 
akuntansi berbasis akrual. Hal ini dapat diatasi Pemerintah Daerah Kota Palembang dengan memakai aplikasi Sistem Informasi Manajemen Daerah (SIMDA), Komitmen Pimpinan, dengan adanya komitmen dan dukungan politik dari pimpinan dan para pengambil keputusan karena dalam pemerintahan, dukungan yang kuat dari pimpinan merupakan kunci keberhasilan dari suatu perubahan.

Hal ini disebabkan penerapan basis akrual membutuhkan pembaruan yang terus menerus sehingga tersedianya dana pemeliharaan pun menjadi mutlak. Pemerintah Kota Palembang melalui Badan Pengelolaan Keuangan dan Aset Daerah Kota Palembang telah mengalokasikan anggaran untuk penerapan akuntansi berbasis akrual setiap tahunnya, dan tersedianya Sumber Daya Manusia (SDM) yang kompeten. Laporan keuangan diwajibkan untuk disusun secara tertib dan disampaikan oleh pemerintah daerah kepada Badan Pemeriksa Keuangan (BPK) selambatnya tiga bulan setelah tahun anggaran berakhir. Penyiapan dan penyusunan laporan keuangan tersebut memerlukan SDM yang memadai dalam menguasai akuntansi pemerintahan. Hal ini yang menjadi permasalahan pada Pemerintah Kota Palembang yaitu kurangnya Sumber Daya Manusia (SDM) yang kompeten baik itu berdasarkan latar belakang pendidikan maupun pengalaman.

Laporan keuangan Badan Pengelolaan Keuangan dan Aset Daerah Kota Palembang memuat informasi yang relevan mengenai posisi keuangan dan seluruh transaksi yang dilakukan oleh suatu entitas pelaporan selama satu periode pelaporan. Laporan keuangan membandingkan realisasi belanja, transfer, pendapatan, dan pembiayaan dengan anggaran yang ditetapkan, mengevaluasi efektivitas dan efisiensi suatu entitas pelaporan, menilai kondisi keuangan, membantu menentukan ketaatannya terhadap peraturan perundangan serta menilai akuntabilitas pemerintahan dalam membuat keputusan.

Timbulnya permasalahan dalam penerapan akuntansi berbasis akrual, maka ada beberapa hal yang perlu dipertimbangkan untuk menggapai keberhasilan (Key Succes Factor) dalam hal penerapan basis akrual. Bahkan dari permasalahan ini juga harus dilakukan langkah strategis yang perlu diterapkan untuk mengatasi permasalahan tersebut.Berdasarkan latar belakang yang telah diungkapkan di atas mengingat bahwa dengan dikeluarkannya PP 71 Tahun 2010 terkait dengan 
Standar Akuntansi Berbasis Akrual Penuh akan efektif pada periode anggaran 2019. Pembahasan ini akan secara kritis menganalisis pencatatan jurnal transaksi yang terjadi di lingkungan Badan Pengelolaan Keuangan dan Aset Daerah Kota Palembang.

\subsection{Perumusan Masalah}

Berdasarkan latar belakang dirumuskan permasalahan:“ Bagaimanakah pencatatan jurnal transaksi di lingkungan Badan Pengelolaan Keuangan dan Aset Daerah Kota Palembang?“

\section{KAJIAN PUSTAKA}

\subsection{Standar Akuntansi Pemerintahan Berbasis Akrual}

Menurut Kieso, et.al (2007:2) pengertian laporan keuangan adalah sebagai berikut Laporan keuangan merupakan sarana yang bisa digunakan oleh entitas untuk mengkomunikasikan keadaan terkait dengan kondisi keuangannya kepada pihak-pihak yang berkepentingan baik yang berasal dari internal entitas maupun eksternal entitas.Dari pengertian di atas dapat diartikan bahwa laporan keuangan dapat dengan jelas memperlihatkan gambaran kondisi keuangan dari suatu organisasi. Laporan keuangan yang merupakan hasil dari kegiatan operasi suatu organisasi akan memberikan informasi keuangan yang berguna bagi organisasi maupun pihak eksternal yang berkaitan dengan organisasi.

\subsection{Laporan Realisasi Anggaran}

Modul gambaran umum Akuntansi Berbasis Akrual yang dikeluarkan oleh Kementerian Keuangan Republik Indonesia, tentang laporan realisasi anggaran (2014:36-53);

Laporan Realisasi Anggaran (LRA) merupakan salah satu laporan keuangan pemerintah yang menyajikan ikhtisar sumber, alokasi dan pemakaian sumber daya yang dikelola oleh pemerintah pusat maupun daerah, yang menggambarkan perbandingan antara anggaran dan realisasinya dalam suatu periode tertentu.

Dari pengertian di atas maka dapat ditarik kesimpulan bahwa laporan realisasi anggaran memberikan gambaran sebagai berikut (SAP,2016:21):

1. Manfaat 
Menyediakan informasi mengenai realisasi pendapatan LRA, belanja, transfer, surplus/deficit-LRA, dan pembiayaan dari suatu entitas pelaporan yang masing-masing diperbandingkan dengan anggarannya. Informasi tersebut berguna bagi para pengguna laporan dalam mengevaluasi keputusan mengenai ketaatan entitas pelaporan terhadap anggaran dengan:

a) Menyediakan informasi mengenai sumber, alokasi, dan penggunaan sumber daya ekonomi;

b) Menyediakan informasi mengenai realisasi anggaran secara menyeluruh yang berguna dalam mengevaluasi kinerja pemerintah dalam hal efisiensi dan efektivitas penggunaan anggaran.

2. Struktur dan Isi

a) Pendapatan-LRA;

1) Pemdapatan-LRA diakui pada saat diterima pada Rekening Kas Umum Negara/Daerah.

2) Pendapatan-LRA diklasifikasikan menurut jenis pendapatan.

3) Transfer masuk adalah penerimaan uang dari entitas pelaporan lain, misalnya penerimaan dana perimbangan dari pemerintah pusat dan dana bagi hasil dari pemerintah provinsi.

4) Akuntansi pendapatan-LRA dilaksanakan berdasarkan azas bruto, yaitu dengan membukukan penerimaan bruto, dan tidak mencatat jumlah netonya (setelah dikompensasikan dengan pengeluaran).

5) Dalam hal besaran pengurang terhadap pendapatan-LRA bruto (biaya) bersifat variable terhadap pendapatan dimaksud dan tidak dianggarkan terlebih dahulu dikarenakan proses belum selesai, maka asas bruto dapat dikecualikan.

3. Transfer

a) Surflus/deficit-LRA; merupakan selisih antara pendapatan-LRA dan belanja selama satu periode pelaporan;

b) Penerimaan pembiayaan;

1) Penerimaan pembiayaan diakui pada saat diterima pada Rekening Kas Umum Negara/Daerah. 
2) Akuntansi penerimaan pembiayaan dilaksanakan berdasarkan azas bruto, yaitu dengan membukukan penerimaan bruto, dan tidak mencatat jumlah neto nya (setelah dikompensasikan dengan pengeluaran).

3) Pengeluaran pembiayaan merupakan Pengeluaran pembiayaan diakui pada saat dikeluarkan dari Rekening Kas Umum Negara/Daerah.

4) Pembiayaan neto merupakan Selisih lebih/kurang antara penerimaan dan pengeluaran pembiayaan selama satu periode pelaporan.

5) Sisa lebih/kurang pembiayaan anggaran (SiLPA/SiKPA) merupakan selisih lebih/kurang antara realisasi pendapatan-LRA dan Belanja, serta penerimaan dan pengeluaran pembiayaan selama satu periode pelaporan.

\subsection{Laporan Operasional}

Laporan Operasional menyajikan berbagai unsur pendapatan-LO, beban, surplus/defisit dari operasi, surplus/deficit dari kegiatan nonoperasional, surplus/defisit sebelum pos luar biasa, pos luar biasa, dan surplus/defisit-LO, yang diperlukan untuk penyajian yang wajar.

1. Pengertian dan Tujuan

Laporan Operasional (LO) disusun untuk melengkapi pelaporan dari siklus akuntansi berbasis akrual (full accrual accounting cycle) sehingga penyusunan Laporan Operasional, Laporan Perubahan Ekuitas, dan Neraca mempunyai keterkaitan yang dapat dipertanggungjawabkan.

2. Manfaat

Menyediakan informasi mengenai seluruh kegiatan operasional keuangan entitas pelaporan yang tercerminkan dalam pendapatan-LO, beban, dan surplus/defisit operasional dari suatu entitas pelaporan yang penyajiannya disandingkan dengan periode sebelumnya.

3. Struktur dan Isi

Struktur Laporan Operasional mencakup pos-pos sebagai berikut:

a. Pendapatan-LO

1) Timbulnya hak atas pendapatan;

2) Pendapatan direalisasi, yaitu adanya aliran masuk sumber daya ekonomi. 
b. Beban

Beban diakui pada saat:

1) Timbulnya kewajiban;

2) Terjadinya konsumsi asset;

3) Terjadinya penurunan manfaat ekonomi atau potensi jasa.

c. Surplus/Defisit dari operasi

Surplus/defisit dari kegiatan operasional adalah selisih lebih/kurang antara pendapatan dan beban selama satu periode pelaporan.

d. Kegiatan non operasional

Pendapatan dan beban yang sifatnya tidak rutin perlu dikelompokkan tersendiri dalam kegiatan non operasional.

e. Surplus/Defisit sebelum Pos Luar Biasa Merupakan selisih lebih/kurang antara surplus/defisit dari kegiatan operasional dan surplus/defisit dari kegiatan non operasional.

f. Pos Luar Biasa

Pos Luar Biasa disajikan terpisah dari pos-pos lainnya dalam Laporan Operasional dan disajikan sesudah Surplus/Defisit sebelum Pos Luar Biasa.

g. Surplus/Defisit-LO

Surplus/Defisit-LO adalah penjumlahan selisih lebih/kurang antara surplus/defisit kegiatan operasional, kegiatan non operasional, dan kejadian luar biasa.

\section{METODOLOGI PENELITIAN}

\subsection{Desain Penelitian}

Desain penelitian yang dilakukan dalam penelitian ini adalah dengan Teknik analisis yang digunakan dalam penelitian ini adalah teknik kuantitatif dengan kata lain ciri penelitian kuantitatif yaitu penelitian yang menggunakan perhitungan atau angka-angka. 


\subsection{Lokasi Penelitian}

Lokasi penelitian dilakukan melalui Badan Pengelolaan Keuangan Dan Asset Daerah Kota Palembang.

\subsection{Metode Pengumpulan dan Analisa Data}

Teknik pengumpulan data yang digunakan dalam penelitian ini adalah Definisi Konsep Utama dalam penelitian yang digunakan oleh peneliti adalah Implemantasi Basis Akrual pada Laporan Keuangan Badan Pengelolaan Keuangan dan Aset Daerah Kota Palembang agar dapat memberikan gambaran yang lebih baik mengenai kinerja pemerintah, sehingga pemerintah dapat membuat kebijakan yang lebih relevan untuk masa depan.

Teknik analisis sdata ini menggunakan Teknik Analisis Deskriptif yaitu penelitian yang berusaha mendeskripsikan suatu gejala, peristiwa, kejadian yang terjadi pada saat sekarang. (Sujana dan Ibrahim, 1989:65) dengan melakukan analisis basis akrual pada suatu laporan keuangan sesuai dengan tata cara penyajian yang tercantum pada Peraturan Pemerintah Republik Indonesia Nomor 71 Tahun 2010 tentang Standar Akuntansi pemerintah.

\section{HASIL DAN PEMBAHASAN}

\subsection{Hasil Penelitian}

Sebagai entitas akuntansi Badan Pengelolaan Keuangan dan Aset Daerah Kota Palembang berkewajiban menyusun dan menyediakan laporan keuangan untuk menyampaikan informasi yang relevan mengenai posisi keuangan dan seluruh transaksi yangn dilakukan SKPD selama satu periode pelaporan. Laporan keuangan yang disusun digunakan untuk membandingkan realisasi pendapatan dan belanja dengan anggaran yang telah ditetapkan, menilai kondisi keuangan, menilai efektivitas dan efisiensi kegiatan serta membantu menentukan ketaatan terhadap peraturan perundangan. Selain itu laporan keuangan menyajikan informasi yang bermanfaat bagi para pengguna laporan dalam menilai akuntabilitas dan membuat keputusan baik keputusan ekonomi, sosial maupun politik.

Akuntansi keuangan Badan Pengelolaan Keuangan dan Aset Daerah Kota Palembang merupakan bagian dari akuntansi sektor publik, yang mencatat dan 
melaporkan semua transaksi yang berkaitan dengan keuangan daerah. Badan Pengelolaan Keuangan dan Aset Daerah Kota Palembang melakukan pelaporan keuangan satu tahun sekali yang diterbitkan paling lambat tanggal 10 Januari. Pembuatan laporan keuangan dilakukan oleh bagian akuntansi/bagian umum dan keuangan/bagian secretariat. Laporan keuangan yang disajikan antara lain, laporan neraca, laporan operasional, laporan realisasi anggaran, laporan perubahan ekuitas dan catatan atas laporan keuangan.

\section{Tabel 1}

Analisis Implementasi Basis Akrual Pada Laporan Keuangan Badan Pengelolaan Keuangan dan Aset Daerah Kota Palembang Tahun 2019

\begin{tabular}{|c|c|c|c|c|}
\hline No. & $\begin{array}{c}\text { Basis Akrual Dalam } \\
\text { Penyajian } \\
\text { Laporan Keuangan }\end{array}$ & $\begin{array}{c}\text { Badan Pengelolaan } \\
\text { Keuangan dan Aset } \\
\text { Daerah Kota Palembang }\end{array}$ & $\begin{array}{l}\text { PP No. } 71 \text { Tahun } \\
2010\end{array}$ & $\begin{array}{c}\text { Sesuai/ } \\
\text { Tidak Sesuai }\end{array}$ \\
\hline 1 & $\begin{array}{l}\text { Laporan Realisasi } \\
\text { Anggaran }\end{array}$ & $\begin{array}{l}\text { Nilai yang disajikan } \\
\text { hanya berupa pagu } \\
\text { anggaran dan belanja . } \\
\text { tidak terdapat transfer } \\
\text { dan pembiayaan }\end{array}$ & $\begin{array}{l}\text { Menyajikan } \\
\text { pendapatan pagu } \\
\text { anggaran dan belanja, } \\
\text { transfer dan } \\
\text { pembiayaan }\end{array}$ & Tidak Sesuai \\
\hline \multirow[t]{5}{*}{2} & $\begin{array}{l}\text { Laporan Perubahan } \\
\text { Ekuitas }\end{array}$ & & & \\
\hline & Ekuitas Awal & $\begin{array}{l}\text { Tidak berasal dari saldo } \\
\text { akhir ekuitas periode } \\
\text { Sebelumnya }\end{array}$ & $\begin{array}{l}\text { Berasal dari saldo } \\
\text { akhir ekuitas periode } \\
\text { tahun sebelumnya }\end{array}$ & Tidak Sesuai \\
\hline & Surplus/Defisit - LO & $\begin{array}{l}\text { Nilai berasal dari } \\
\text { surplus/defisit - LO } \\
\text { dalam laporan } \\
\text { Operasional }\end{array}$ & $\begin{array}{l}\text { Berasal dari nilai } \\
\text { surplus/defisit - LO } \\
\text { dalam laporan } \\
\text { operasional }\end{array}$ & Sesuai \\
\hline & $\begin{array}{l}\text { Koreksi-Koreksi } \\
\text { Kesalahan }\end{array}$ & $\begin{array}{l}\text { Koreksi kesalahan dari } \\
\text { nilai persediaan, selisih } \\
\text { revaluasi aset tetap dan } \\
\text { koreksi ekuitas lainnya }\end{array}$ & $\begin{array}{l}\text { Koreksi kesalahan dari } \\
\text { persediaan, nilai } \\
\text { revaluasi aset tetap } \\
\text { dan lain-lain }\end{array}$ & Sesuai \\
\hline & Ekuitas Akhir & $\begin{array}{l}\text { Nilai yang diperoleh dari } \\
\text { nilai ekuitas pada } \\
\text { laporan neraca }\end{array}$ & $\begin{array}{l}\text { Nilai yang diperoleh } \\
\text { dari selisih ekuitas } \\
\text { awal, surplus/ defisit- } \\
\text { LO, dan koreksi- } \\
\text { koreksi kesalahan }\end{array}$ & Tidak sesuai \\
\hline \multirow[t]{2}{*}{3} & $\begin{array}{l}\text { Laporan } \\
\text { Operasional }\end{array}$ & & & \\
\hline & Pendapatan - LO & $\begin{array}{l}\text { Terdapat Pendapatan - } \\
\text { LO yang disajikan } \\
\text { dalam laporan keuangan } \\
\text { SKPD baik pendapatan } \\
\text { PAD-LO, transfer-LO } \\
\text { dan pendapatan lain- } \\
\text { lain-LO }\end{array}$ & $\begin{array}{l}\text { Berasal dari kegiatan } \\
\text { operasional yaitu } \\
\text { pendapatan asli daerah } \\
\text {-LO, pendapatan } \\
\text { transfer-LO dan } \\
\text { pendapatan lain-lain- } \\
\text { LO berasal dari pajak }\end{array}$ & Sesuai \\
\hline
\end{tabular}




\begin{tabular}{|l|l|l|l|l|}
\hline No. & $\begin{array}{c}\text { Basis Akrual Dalam } \\
\text { Penyajian } \\
\text { Laporan Keuangan }\end{array}$ & $\begin{array}{c}\text { Badan Pengelolaan } \\
\text { Keuangan dan Aset } \\
\text { Daerah Kota Palembang }\end{array}$ & $\begin{array}{c}\text { PP No. 71 Tahun } \\
\mathbf{2 0 1 0}\end{array}$ & $\begin{array}{c}\text { Sesuai/ } \\
\text { Tidak Sesuai }\end{array}$ \\
\hline & Beban & $\begin{array}{l}\text { Akun beban diakui pada } \\
\text { saat timbulnya }\end{array}$ & $\begin{array}{l}\text { Aketribusi, dana } \\
\text { alokasi khusus dan } \\
\text { hibah dari pemerintah } \\
\text { kota maupun provinsi. } \\
\text { pada saat timbulnya }\end{array}$ & Sesuai \\
\hline
\end{tabular}

Tabel 2

Analisis Implementasi Basis Akrual Pada Laporan Keuangan Badan Pengelolaan Keuangan dan Aset Daerah Kota Palembang Tahun 2019

\begin{tabular}{|c|c|c|c|c|}
\hline No. & $\begin{array}{c}\text { Basis Akrual Dalam } \\
\text { Penyajian Laporan } \\
\text { Keuangan }\end{array}$ & $\begin{array}{c}\text { Badan Pengelolaan } \\
\text { Keuangan dan Aset } \\
\text { Daerah Kota Palembang }\end{array}$ & $\begin{array}{c}\text { PP No. } 71 \text { Tahun } \\
2010\end{array}$ & $\begin{array}{l}\text { Sesuai/ } \\
\text { Tidak } \\
\text { Sesuai }\end{array}$ \\
\hline 1 & Surplus/defisit & $\begin{array}{l}\text { kewajiban, terjadinya } \\
\text { konsumsi aset, dan } \\
\text { penurunan manfaat } \\
\text { ekonomi barang/ jasa. } \\
\text { Beban berasal dari } \\
\text { beban operasi, beban } \\
\text { transfer dan beban luar } \\
\text { Biasa }\end{array}$ & $\begin{array}{l}\text { kewajiban, terjadinya } \\
\text { konsumsi aset, dan } \\
\text { penurunan manfaat } \\
\text { ekonomi barang/ jasa. } \\
\text { Beban berasal dari } \\
\text { beban operasi, beban } \\
\text { transfer dan beban } \\
\text { lain-lain }\end{array}$ & \\
\hline 2 & $\begin{array}{l}\text { Surplus/defisit } \\
\text { kegiatan operasional } \\
\text {-LO }\end{array}$ & $\begin{array}{l}\text { Nilai diperoleh dari } \\
\text { selisih antara pendapatan } \\
\text { - LO dan beban-LO }\end{array}$ & $\begin{array}{l}\text { Selisih antara } \\
\text { pendapatan-LO dan } \\
\text { beban-LO }\end{array}$ & Sesuai \\
\hline 3 & $\begin{array}{l}\text { Surplus/defisit } \\
\text { kegiatan non } \\
\text { operasional - LO }\end{array}$ & $\begin{array}{l}\text { Berasal dari surplus/ } \\
\text { defisit penjualan aset } \\
\text { non lancar dan surplus/ } \\
\text { defisit non operasional } \\
\text { lainnya- } \\
\text { LO }\end{array}$ & $\begin{array}{l}\text { Berasal dari surplus/ } \\
\text { defisit penjualan asset } \\
\text { non lancar dan } \\
\text { surplus/ defisit non } \\
\text { operasional lainnya- } \\
\text { LO }\end{array}$ & Sesuai \\
\hline 4 & Surplus/defisit-LO & $\begin{array}{l}\text { Berasal dari Selisih } \\
\text { antara surplus/defisit } \\
\text { operasional dan surplus/ } \\
\text { defisit non operasional }\end{array}$ & $\begin{array}{l}\text { Selisih antara surplus/ } \\
\text { defisit operasional } \\
\text { dan } \\
\text { surplus/defisit non } \\
\text { operasional }\end{array}$ & Sesuai \\
\hline 5 & Laporan Neraca & Posisi keuangan entitas & Menjelaskan posisi & \\
\hline & & $\begin{array}{l}\text { terdiri dari aset, } \\
\text { kewajiban dan ekuitas }\end{array}$ & $\begin{array}{l}\text { keuangan yang } \\
\text { meliputi aset, } \\
\text { kewajiban } \\
\text { ekuitas } \\
\text { secara lengkap }\end{array}$ & Sesuai \\
\hline 6 & Aset Lancar & Aset lancar yang & Kas dan setara kas, & \\
\hline
\end{tabular}




\begin{tabular}{|c|l|l|l|l|} 
& & $\begin{array}{l}\text { dimiliki entitas yaitu } \\
\text { kas dan setara kas, } \\
\text { persediaan, piutang, } \\
\text { beban dibayar di muka, } \\
\text { investasi jangka pendek }\end{array}$ & piutang, persediaan & Sesuai \\
\hline 7 & Aset Tetap & $\begin{array}{l}\text { Terdiri dari tanah, } \\
\text { gedung dan bangunan, } \\
\text { peralatan mesin, jalan } \\
\text { irigasi dan akumulasi } \\
\text { Penyusutan }\end{array}$ & $\begin{array}{l}\text { Tanah, gedung dan } \\
\text { bangunan, peralatan } \\
\text { mesin, jalan irigasi } \\
\text { dan akumulasi } \\
\text { Penyusutan }\end{array}$ & Sesuai \\
\hline 8 & Aset tak Berwujud & $\begin{array}{l}\text { Software } \\
\text { Software, merk } \\
\text { dagang, licensi dan } \\
\text { Amortisasi }\end{array}$ & Sesuai \\
\hline 9 & Ekuitas & $\begin{array}{l}\text { Saldo ekuitas di neraca } \\
\text { berasal dari saldo akhir } \\
\text { ekuitas pada laporan } \\
\text { perubahan ekuitas }\end{array}$ & $\begin{array}{l}\text { Saldo ekuitas di } \\
\text { neraca berasal dari } \\
\text { saldo akhir ekuitas } \\
\text { pada laporan } \\
\text { perubahan ekuitas }\end{array}$ & Sesuai \\
\hline
\end{tabular}

\begin{tabular}{|c|c|c|c|c|}
\hline No. & $\begin{array}{c}\text { Basis Akrual Dalam } \\
\text { Penyajian Laporan } \\
\text { Keuangan }\end{array}$ & $\begin{array}{c}\text { Badan Pengelolaan } \\
\text { Keuangan dan Aset Daerah } \\
\text { Kota Palembang }\end{array}$ & $\begin{array}{c}\text { PP No. } 71 \text { Tahun } \\
2010\end{array}$ & $\begin{array}{l}\text { Sesuai/ } \\
\text { Tidak } \\
\text { Sesuai }\end{array}$ \\
\hline 10 & $\begin{array}{l}\text { Catatan atas } \\
\text { Laporan Keuangan }\end{array}$ & & & \\
\hline \multirow[t]{2}{*}{11} & Umum & $\begin{array}{l}\text { Menjelaskan maksud } \\
\text { tujuan penyusunan } \\
\text { laporan keuangan }\end{array}$ & $\begin{array}{l}\text { Laporan keuangan } \\
\text { tujuan umum entitas }\end{array}$ & Sesuai \\
\hline & & $\begin{array}{l}\text { Gambaran lengkap } \\
\text { Profil Badan } \\
\text { Kepegawaian dan SDM } \\
\text { Kota Palembang }\end{array}$ & $\begin{array}{l}\text { Entitas akuntansi } \\
\text { Pelaporan }\end{array}$ & Sesuai \\
\hline 12 & $\begin{array}{l}\text { Pengungkapan } \\
\text { kebijakan akuntansi }\end{array}$ & $\begin{array}{l}\text { Menjelaskan basis } \\
\text { akuntansi yang } \\
\text { digunakan dan } \\
\text { pengukuran yang } \\
\text { mendasari penyusunan } \\
\text { laporan keuangan }\end{array}$ & $\begin{array}{l}\text { Pengungkapan dan } \\
\text { pengukuran terkait } \\
\text { basis akuntansi yang } \\
\text { mendukung laporan } \\
\text { keuangan }\end{array}$ & Sesuai \\
\hline 13 & $\begin{array}{l}\text { Pos-pos laporan } \\
\text { keuangan }\end{array}$ & $\begin{array}{l}\text { Penjelasan rinci tiap } \\
\text { pos-pos laporan } \\
\text { keuangan }\end{array}$ & $\begin{array}{l}\text { Menjelaskan tiap } \\
\text { pos- } \\
\text { pos dan akun yang } \\
\text { digunakan dalam } \\
\text { laporan keuangan } \\
\text { secara rinci }\end{array}$ & Sesuai \\
\hline 14 & Laporan realisasi & Tidak terdapat & $\begin{array}{l}\text { Menjelaskan rinci } \\
\text { pos- }\end{array}$ & \\
\hline 15 & anggaran & $\begin{array}{l}\text { penerimaan yang dapat } \\
\text { diakui sebagai } \\
\text { pendapatan. }\end{array}$ & $\begin{array}{l}\text { pos pendapatan, } \\
\text { belanja, transfer dan } \\
\text { pembiayaan }\end{array}$ & \\
\hline
\end{tabular}




\begin{tabular}{|c|c|c|c|c|}
\hline No. & $\begin{array}{c}\text { Basis Akrual Dalam } \\
\text { Penyajian Laporan } \\
\text { Keuangan }\end{array}$ & \begin{tabular}{|c|} 
Badan Pengelolaan \\
Keuangan dan Aset Daerah \\
Kota Palembang
\end{tabular} & $\begin{array}{c}\text { PP No. } 71 \text { Tahun } \\
2010\end{array}$ & $\begin{array}{l}\text { Sesuai/ } \\
\text { Tidak } \\
\text { Sesuai }\end{array}$ \\
\hline 16 & & $\begin{array}{l}\text { Tidak terdapat transfer } \\
\text { dan pembiayaan } \\
\text { Menjelaskan pagu } \\
\text { anggaran dan pos } \\
\text { belanja secara rinci yaitu } \\
\text { belanja operasi, belanja } \\
\text { barang jasa, dan belanja } \\
\text { Modal }\end{array}$ & & $\begin{array}{l}\text { Tidak } \\
\text { Sesuai }\end{array}$ \\
\hline 17 & Neraca & $\begin{array}{l}\text { Meliputi pos kas di } \\
\text { bendahara pengeluaran, } \\
\text { persediaan, aset tetap, } \\
\text { aset tak berwujud dan } \\
\text { Ekuitas }\end{array}$ & $\begin{array}{l}\text { Menjelaskan secara } \\
\text { rinci pos-pos dalam } \\
\text { laporan posisi } \\
\text { keuangan (neraca) } \\
\text { dibandingkan tahun } \\
\text { sebelumnya }\end{array}$ & Sesuai \\
\hline 18 & & $\begin{array}{l}\text { Menjelaskan mutasi dari } \\
\text { persediaan dibandingkan } \\
\text { tahun } 2015\end{array}$ & $\begin{array}{l}\text { Menjelaskan } \\
\text { kenaikan } \\
\text { penurunan dari } \\
\text { persediaan } \\
\text { dibandingkan tahun } \\
\text { sebelumnya }\end{array}$ & Sesuai \\
\hline 19 & & $\begin{array}{l}\text { Menjelaskan perolehan } \\
\text { tanah, peralatan mesin, }\end{array}$ & $\begin{array}{l}\text { Menjelaskan mutasi } \\
\text { dari aset tetap dan }\end{array}$ & Sesuai \\
\hline 20 & & $\begin{array}{l}\text { gedung bangunan dan } \\
\text { jalan dan irigasi, serta } \\
\text { akumulasi penyusutan }\end{array}$ & $\begin{array}{l}\text { akumulasi } \\
\text { penyusutan } \\
\text { dibandingkan tahun } \\
\text { sebelumnya } \\
\end{array}$ & \\
\hline 21 & & $\begin{array}{l}\text { Menjelaskan perolehan } \\
\text { aset tetap lainnya berupa } \\
\text { software SKPD dan } \\
\text { amortisasi }\end{array}$ & $\begin{array}{l}\text { Sesuai SAP } 71 \\
\text { software termasuk } \\
\text { dalam aset tak } \\
\text { berwujud }\end{array}$ & Sesuai \\
\hline 22 & & $\begin{array}{l}\text { Menjelaskan mutasi } \\
\text { ekuitas hanya pada } \\
\text { laporan keuangan } 2017\end{array}$ & $\begin{array}{l}\text { Menjelaskan } \\
\text { kenaikan } \\
\text { penurunan } \\
\text { ekuitas } \\
\text { dibandingkan tahun } \\
\text { sebelumnya } \\
\end{array}$ & $\begin{array}{l}\text { Tidak } \\
\text { Sesuai }\end{array}$ \\
\hline 23 & Laporan Operasional & $\begin{array}{l}\text { Menjelaskan akun-akun } \\
\text { dalam laporan } \\
\text { operasional pada CALK }\end{array}$ & $\begin{array}{l}\text { Menjelaskan saldo } \\
\text { pendapatan-LO dan } \\
\text { beban, surplus/ } \\
\text { defisit- } \\
\text { LO dan non } \\
\text { operasional }\end{array}$ & Sesuai \\
\hline 24 & $\begin{array}{l}\text { Laporan perubahan } \\
\text { ekuitas }\end{array}$ & $\begin{array}{l}\text { Menjelaskan akun-akun } \\
\text { dalam laporan } \\
\text { perubahan ekuitas pada }\end{array}$ & $\begin{array}{l}\text { Menjelaskan lengkap } \\
\text { pos-pos ekuitas awal, } \\
\text { surplus/defisit, } \\
\text { koreksi }\end{array}$ & \\
\hline
\end{tabular}




\begin{tabular}{|c|c|c|c|c|}
\hline$N_{0}$ & $\begin{array}{c}\text { Basis Akrual Dalam } \\
\text { Penyajian Laporan } \\
\text { Keuangan }\end{array}$ & $\begin{array}{c}\text { Badan Pengelolaan } \\
\text { Keuangan dan Aset Daerah } \\
\text { Kota Palembang }\end{array}$ & $\begin{array}{c}\text { PP No. } 71 \text { Tahun } \\
2010\end{array}$ & $\begin{array}{l}\text { Sesuai/ } \\
\text { Tidak } \\
\text { Sesuai }\end{array}$ \\
\hline & & CALK & $\begin{array}{l}\text { dan ekuitas akhir } \\
\text { yang } \\
\text { diperoleh }\end{array}$ & \\
\hline 25 & Pengungkapan - & Menjelaskan Domisili & Mengunakan & \\
\hline 26 & $\begin{array}{l}\text { pengungkapan } \\
\text { lainnya }\end{array}$ & $\begin{array}{l}\text { dan bentuk hukum suatu } \\
\text { entitas serta jurisdiksi } \\
\text { dimana entitas tersebut } \\
\text { beroperasi; Penjelasan } \\
\text { mengenai sifat operasi } \\
\text { entitas dan kegiatan } \\
\text { pokoknya; Ketentuan } \\
\text { perundang-undangan } \\
\text { yang menjadi landasan } \\
\text { kegiatan operasionalnya }\end{array}$ & $\begin{array}{l}\text { kejadiankejadian } \\
\text { penting selama } \\
\text { tahun pelaporan }\end{array}$ & Sesuai \\
\hline
\end{tabular}

Sumber : Data Diolah Penulis, 2021

Berdasarkan hasil analisis implementasi pada tabel 4.5 diketahui bahwa penyajian laporan keuangan Badan Pengelolaan Keuangan dan Aset Daerah Kota Palembang masih ada yang tidak sesuai dengan Peraturan Pemerintah Republik Indonesia Nomor 71 tahun 2010 yaitu khususnya pada penyajian laporan realisasi anggaran, laporan perubahan ekuitas dan catatan atas laporan keuangan. Dari total item kondisi pada Peraturan Pemerintah Republik Indonesia Nomor 71 Tahun 2010 yaitu sebesar 28 item kondisi ditemukan 4 kondisi dalam laporan keuangan yang masih tidak sesuai dengan Peraturan Pemerintah Republik Indonesia Nomor 71 Tahun 2010. Sehingga dapat disimpulkan bahwa 85,71\% laporan keuangan Badan Pengelolaan Keuangan dan Aset Daerah Kota Palembang sudah sesuai dengan Peraturan Pemerintah Republik Indonesia Nomor 71 Tahun 2010.

Sedangkan dari penelitian terdahulu oleh Junikasih Sophia Watubun (2014) penerapan SAP berbasis akrual di Dinas Pendapatan, Pengelola Keuangan dan Aset Daerah Kabupaten Situbondo akan dilaksanakan penuh pada tahun anggaran 2016. Akan tetapi, dalam mengimplementasikan Laporan Keuangan tersebut menemui beberapa kendala, yaitu sistem dan aplikasi yang digunakan, resistensi terhadap perubahan, kurangnya SDM yang berkompeten dan dukungan penuh dari pimpinan. Kendala-kendala tesebut diharapkan adanya pengendalian internal yang memadai agar tercapainya Laporan Keuangan Basis Akrual yang efektif dan efisien dan keandalan pelaporan keuangan. 
Hubungan hasil penelitian ini dengan penelitian terdahulu tentunya dapat dilihat persamaanya dimana semuanya membahas tentang Standar Akuntansi Pemerintahan.

\section{SIMPULAN DAN SARAN}

\subsection{Simpulan}

Berdasarkan hasil penelitian yang ditemukan dapat disimpulkan bahwa Implementasi basis akrual pada laporan keuangan Badan Pengelolaan Keuangan dan Aset Daerah Kota Palembang masih belum sesuai dengan Peraturan Pemerintah Republik Indonesia Nomor 71 Tahun 2010 dalam menyajikan laporan keuangannya. Ketidaksesuaian ini terjadi pada 3 (tiga) laporan yang disajikan Badan Pengelolaan Keuangan dan Aset Daerah Kota Palembang yang tidak sesuai dengan tata cara penyajian yang tercantum pada Peraturan Pemerintah Republik Indonesia Nomor 71 Tahun 2010 tentang Standar Akuntansi pemerintah. Laporan yang masih belum sesuai tersebut adalah laporan realisasi anggaran belanja, laporan perubahan ekuitas dan Catatan atas Laporan Keuangan.

\subsection{Saran}

Berdasarkan kesimpulan di atas, maka penulis memberikan saran Bagi Badan Pengelolaan Keuangan dan Aset Daerah Kota Palembang agar lebih memperhatikan kesesuaian dalam penyajian laporannya terutama untuk laporan realisasi anggaran dan laporan perubahan ekuitas serta Catatan atas Laporan Keuangan.

\section{DAFTAR PUSTAKA}

Alma, Buchari Prof, Dr. Manajemen Pemasaran \& Pemasaran Jasa, Edisi Revisi Cetakan ke-enam, 2004, Penerbit Alfarberta ,Bandung.

Bernadetta Dwiyani Aninditta 2012, Analisis Kepuasan Pelanggan Pada Alfamart Tembalang Dari Dimensi Pelayanan.

Fandy Tjiptono, 2000, Manajemen Jasa, Penerbit Andi, Jogyakarta.

Irawan Handi, 2002, Service Marketing, Penerbit Andi, Jogyakarta.

Kotler, Philp, Manajemen Pemasaran, Alih Bahasa, Benyamin Molan; Penyunting Bambang Sarwiji, Edisi 11, Jilid I, Jakarta, Indeks, 2005. 
Kotler, Philp, Manajemen Pemasaran, Alih Bahasa, Benyamin Molan; Penyunting Bambang Sarwiji, Edisi 11, Jilid II, Jakarta, Indeks, 2005.

Kotler, Philp, Manajemen Pemasaran, Jilid 1, Edisi Ke 10, Penerbit PT Perharlindo, Jakarta.

Lupiyoadi, Rambat, Manajemen Pemasaran Jasa, Edisi Pertama, Jakarta, Salemba Empat, 2001.

Parasian Manurung 2017, Pengaruh Promosi, Harga, Kualitas Pelayanan Terhadap Kepuasan Konsumen Dan Keputusan Pembelian Ulang di Alfamart Dan Indomaret.

Sugiyono, Metode Penelitian Bisnis, Edisi 5 Bandung, CV Alfabeta, 2001.

Supardi Nani,SE.,M.Si NIP.,Tineke Wolok, ST.,MM 2014, Analisis Kualitas Pelayanan Terhadap Kepuasan Pelanggan Pada PT. Bank Sinar Mas Cabang Gorontalo. 